\title{
Invasive goldenrods affect abundance and diversity of grassland ant communities (Hymenoptera: Formicidae)
}

\author{
Joanna Kajzer-Bonk ${ }^{1} \cdot$ Damian Szpiłyk $^{1} \cdot$ Michał Woyciechowski $^{1}$
}

Received: 23 September 2015/ Accepted: 6 January 2016/Published online: 11 January 2016

(C) The Author(s) 2016. This article is published with open access at Springerlink.com

\begin{abstract}
Goldenrods (Solidago sp.) are currently one of the most invasive plant species in Central Europe. They threaten abandoned semi-natural wet grasslands which are extremely vulnerable to plant succession and invasions. We assessed whether Solidago invasion affects ants, keystone organisms essential to proper ecosystem functioning and to the existence of myrmecophilous Phengaris butterflies. Ten meadows containing 60 plots with and without goldenrods were studied. We found a strong, negative dependence between the presence of goldenrod cover and the number of ant nests (more than $50 \%$ reduction compared to control) as well as the number of species, and changes in species composition. Myrmica ants, essential hosts for Phengaris larvae, were among the most affected species by goldenrod invasion. Immediate action should be undertaken for restoration and maintenance of biodiversity hotspots affected by goldenrod invasion.
\end{abstract}

Keywords Goldenrod - Invasion · Maculinea butterflies · Solidago canadensis $\cdot$ Solidago gigantea $\cdot$ Semi-natural grasslands

\section{Introduction}

The invasion of alien goldenrods (Solidago gigantea and $S$. canadensis, Asteraceae) is one of the major threats for semi-natural habitats in Central Europe. Introduced from North America in the first half of the nineteenth century as

Joanna Kajzer-Bonk

joanna.kajzer.bonk@gmail.com

1 Institute of Environmental Sciences, Jagiellonian University, Gronostajowa 7, 30-387 Kraków, Poland an ornamental plant, goldenrods began to spread rapidly into new areas, successfully competing and displacing native flora (Weber 1998). Their success is due to strong colonization ability-single plants grow rapidly up to $2 \mathrm{~m}$ height and can produce up to ten thousand light, winddispersed, seeds (Kabuce and Priede 2010). Moreover, they propagate extremely efficiently by rhizomes, the primary proliferation route in stable populations (Hartnett and Bazzaz 1985; Weber 2011). Goldenrods also produce allelopathic compounds, effectively inhibiting the growth of other plants (Abhilasha et al. 2008; Callaway and Aschehoug 2000). The expansion of alien goldenrods is also reinforced by a lack of herbivores (Jobin et al. 1996), viruses and pathogens (Mitchell and Power 2003). Additionally, smaller or slower growing plant species receive less light, resulting in the displacement of native flora (Banta et al. 2008). Uncontrolled growth of Solidago may lead to a reduction in both the number of indigenous plant species and the degree of plant cover by more than $50 \%$ (Moroń et al. 2009). In consequence, goldenrods establish stable and widespread monocultures, with high densities of sprouts. Such large changes in vegetation also bring further consequences for organisms at higher trophic levels, both herbivores and predators (de Groot et al. 2007; Moroń et al. 2009; Skórka et al. 2010; Fenesi et al. 2015). An investigation into the climatic niche of Solidago showed that its range and density will increase, mainly in the south-eastern part of Europe (Weber 2001).

The abandonment of traditional management (mowing, cattle grazing) of semi-natural grasslands (Luoto et al. 2003; Joyce 2014) results in rapid succession within these areas and encroachment of invasive species on previously unavailable habitat, threatening biodiversity (Queiroz et al. 2014). Meadows are among the most endangered habitats in Europe. From the twentieth century, the areas occupied 
by semi-natural grassland have been reduced by at least $80 \%$ of their original area (Joyce 2014). Semi-natural meadows are considered to be valuable for nature protection in Europe and fall under Annex I of the Habitats Directive of the "Natura 2000" network. They are characterized by relatively high biodiversity (Habel et al. 2013) including rare and endangered species closely associated with this specific biotope.

Ants are considered keystone species with an environmental influence disproportionately large in relation to their biomass (Folgarait 1998; Crist 2009). In one season, ants are able to consume $3 \%$ of the primary productivity of meadows and in the case of predatory ants up to $40 \%$ of the biomass (Petal 1980). Ants also have an important role in modifying the physico-chemical properties of the soil. Corridor and nest building by ants not only increases the porosity of the soil by bioturbation, but also alters the $\mathrm{pH}$ and chemical composition, facilitating soil colonization by microbiota and hence increasing the rate of decomposition (Frouz and Jilková 2008). Moreover, ant activity can significantly affect vegetation. The creation of nests favors the colonization of plant roots by mycorrhizal fungi (Dauber et al. 2008) and disturbance to the soil can improve the development of annual plants, some of which are exclusively associated with anthills (Dostál 2007). Ants also spread plant seeds enabling expansion into new areas (Servigne and Detrain 2008). In the case of plant species that use obligatory myrmecochory, displacement of associated ants may cause a significant reduction in population size and may lead to local extinction (Gorb et al. 2013).

There are also strong links between ants and other invertebrates, i.e. aphids and numerous lycaenid butterflies, including the scarce large blue Phengaris teleius, the dusky large blue $P$. nausithous and alcon blue $P$. alcon. All are obligatory parasites of the ant genus Myrmica, spending major parts of their life cycles in ant nests (Thomas et al. 1989; Thomas and Settele 2004). Metapopulations of blue butterflies in Kraków are considered to be one of the largest in Europe (Nowicki et al. 2007) and have been afforded habitat protection in the "Dębnicko-Tyniecki meadow area" of the Natura 2000 network. As an umbrella species, their preservation entails protection for multiple coexisting species and the whole semi-natural meadow habitat.

Because of the unique interactions between different meadow species, interspecific competition among ants can play an important role in the functioning of the whole habitat. Among native meadow-inhabiting ants, Lasius niger is a highly competitive species, resistant to changes and thus dominant in disturbed habitats. It may displace other species of ants such as L. flavus, and Myrmica sp. However, in the case of habitats with high stability, these species may be able to effectively compete with $L$. niger (Wynhoff et al. 2011).
Ants are sensitive to environmental changes and it is relatively easy to estimate their density, making them useful bioindicators (Underwood and Fisher 2006). Some studies have shown changes in ant communities due to abandonment of semi-natural grassland (Dauber et al. 2006; Wynhoff et al. 2011) suggesting that the quickly progressing invasion of goldenrod can also have an impact on this group of insects.

Our aim was to assess whether the invasion of goldenrods on semi-natural grassland areas triggered changes in species composition and population density of meadowinhabiting ants. We checked whether and how goldenrods affect ant communities by assessing the number of ant species, the density of ant nests and proportion of $L$. niger in the total nest number of Myrmica and Lasius species. A negative impact of goldenrods would imply that the invasion is harmful not only to ants, but also indirectly to Phengaris butterflies as well as to the functioning of the ecosystem.

\section{Materials and methods}

The study was conducted in ten semi-natural wet grasslands located in the south-eastern part of Kraków (Fig. 1) which belong to a meadow complex inhabited by Phengaris butterfly metapopulations (Nowicki et al. 2007). Five of them are situated in the "Dębnicko-Tyniecki meadow area" Natura 2000 network. Until recently, these meadows were extensively managed. At present, because of the abandonment of traditional use in all of the surveyed areas,

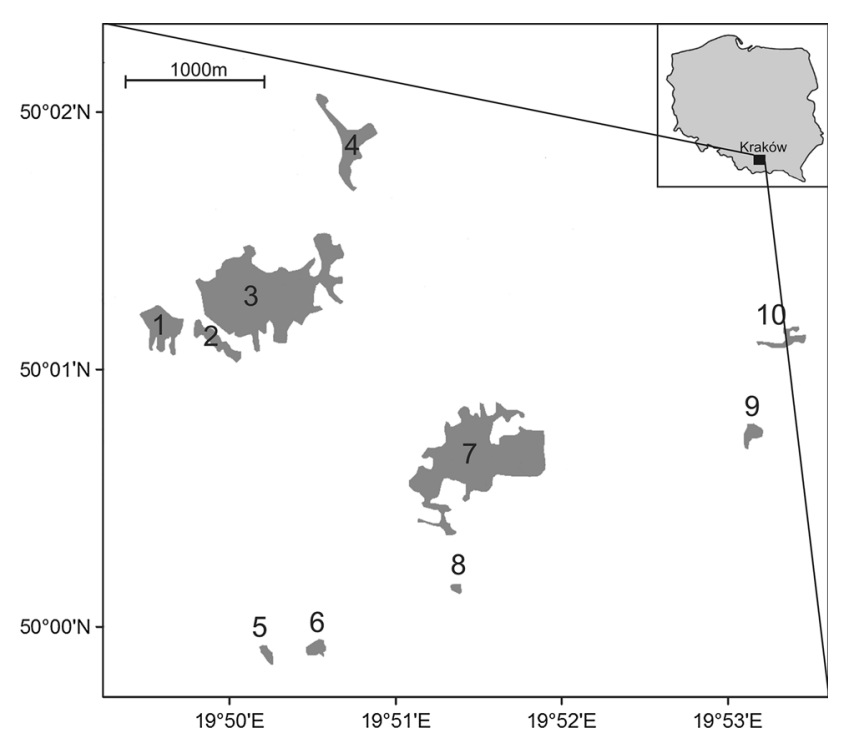

Fig. 1 Location of the studied meadows in the Kraków region, southern Poland 
there is a serious problem with uncontrolled spreading of goldenrod populations.

On each meadow, six $5 \times 5 \mathrm{~m}$ square plots were randomly selected (Łomnicki 2010): three covered with goldenrods (Solidago canadensis and S. gigantea) and three controls. Overall 60 plots were studied. Google Earth photos of each meadow were put on axes according to cardinal directions (' $x$ ' and ' $y$ ' axes demarcated east-west and north-south orientations, respectively). Points on axes were selected using random numbers; their intersection determined coordinates. Next, the list of coordinates was entered into a GPS device. These coordinates determined the southwestern corner of each plot. Plots were located at least $20 \mathrm{~m}$ from each other. Goldenrod cover on each plot was quantified using the Braun-Blanquet Cover-Abundance Scale (Wikum and Shanholtzer 1978; Wysocki and Sikorski 2002) in five categories: $(1-<10 \%$ of goldenrod cover; $2-10-25 \%$ of goldenrod cover; $3-25-50 \%$ of goldenrod cover; 4-50-75\% of goldenrod cover; 5$75-100 \%$ of goldenrod cover). With the exception of two cases (plot cover approximately $65 \%$-category 4 ), we took into consideration only two categories: 1 ('control' plot) and 5 ('goldenrod' plot). Hence if the coordinates did not meet the requirements (i.e. unsuitable meadow type or proximity to other plots), we reiterated the random selection procedure until we obtained 3 plots in each meadow type (3 'goldenrod' and 3 'control').

Each square was investigated in terms of ant nest presence. The study plots were searched systematically to detect all ant nests. Several ant workers were collected from each nest and preserved in $75 \%$ ethyl alcohol for further identification. All samples were collected in the period from 8 June to 9 September 2012, with the exception of a single square, which was inspected on 31 August 2011. Ants were identified using the key of Radchenko et al. (2004). M. scabrinodis and M. sabuleti were grouped together as "M. scabrinodis" because of the minor morphological differences between the species making proper identification contentious. The only certain method in this case seems to be chromatography (Guillem et al. 2012), but due to the very large number of contentious samples and low probability of finding $M$. sabuleti in this area, this species was omitted in the analysis.

Because of non-normal distributions of the collected data, Mann-Whitney $U$ tests were applied to compare the numbers of nests of Myrmica as well as individual ant species between goldenrod and control plots. Next, the average (1) number of ant species, (2) number of ant nests and (3) proportion of $L$. niger ants in the total nest number of Myrmica and Lasius species were calculated for plot type (goldenrod vs. control) on each meadow separately. The mean values for each meadow were used to examine differences between control and goldenrod plots. The Student's $t$ test for paired samples with a $95 \%$ confidence interval was applied to evaluate the impact of goldenrods on the number of ant nests. Data was square-rooted to obtain a normal distribution. In the case of the number of ant species as well as the proportion of $L$. niger ants in the total nest number of Myrmica and Lasius species, data distributions were non-normal even after transformation. Hence, non-parametric Wilcoxon sign-ranked tests were used to check for differences between control and goldenrod meadows. A two-dimensional non-metric multidimensional scaling (NMDS) ordination plot was calculated for visualization of the species composition in both meadow types. One-way PERMANOVA was performed to test for potential differences in ant composition between control and goldenrod plots. Similarly, average nest numbers of each species for each meadow were used to examine differences between control and goldenrod plots. The Bray-Curtis distance was used as a dissimilarity measure because it is well suited for species abundance data (Quinn and Keough 2002). Analyses were done in StatSoft Statistica 12 and PAST 3.

\section{Results}

We found a total of 1087 ant nests belonging to seven species. Myrmica was the most common in the ant assemblage and was more numerous in control than in goldenrod plots (mean \pm SD: $5.19 \pm 8.55 ; 2.12 \pm 5.24$, respectively; Mann-Whitney $U$ test $\mathrm{U}=155.0$; $\mathrm{Z}=4.360 ; P<0.0001)$. Differences in the number of nests between control and goldenrod plots were statistically significant in the case of $M$. ruginodis and $M$. scabrinodis (81\% for M. ruginodis: Mann-Whitney $U$ test $\mathrm{U}=330.5$, $\mathrm{Z}=1.993, \quad P=0.046 ; \quad 63 \%$ for $M . \quad$ scabrinodis: $\mathrm{U}=176.0, \quad \mathrm{Z}=4.082, \quad P<0.001) . \quad$ Non-significantly lower densities in goldenrod plots were found for $M$. rubra and L. flavus (39\% for M. rubra: Mann-Whitney $U$ test $\mathrm{U}=442.0, \mathrm{Z}=0.113 ; P=0.910 ; 65 \%$ for $L$. flavus: $\mathrm{U}=357.5, \mathrm{Z}=1.649, P=0.099)$. The only species that sustained densities and even showed a slightly higher frequency in goldenrod plots (by $2 \%$, Mann-Whitney $U$ test $\mathrm{U}=447.0, \mathrm{Z}=0.041, P=0.968)$ was $L$. niger. Single nests of $M$. gallienii and Formica sp. ants occurred only in the control plots.

The number of species per plot (mean \pm SE) averaged $3.03 \pm 0.69$ for the control and $2.3 \pm 0.66$ for the goldenrod plots and this difference was statistically significant (Wilcoxon-ranked test, $\mathrm{N}=10, \mathrm{~T}=5.00, \mathrm{Z}=2.293$, $P=0.022$; Fig. 2a). Moreover, there was a two-fold difference in the number of ant nests in the control compared to goldenrod plots $(24.97 \pm 7.83$ and $11.27 \pm 6.54$, respectively, Student's $T$ test for paired samples $\mathrm{N}=10$, $\mathrm{DF}=9, \mathrm{~T}=8.871, P<0.001 ;$ Fig. $2 \mathrm{~b})$. There was also a slightly higher proportion of L. niger nests in goldenrod 
(a)

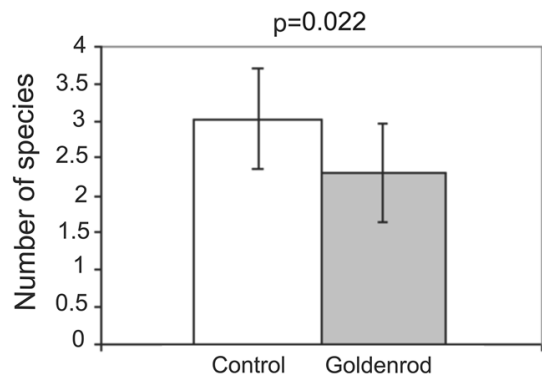

(b)

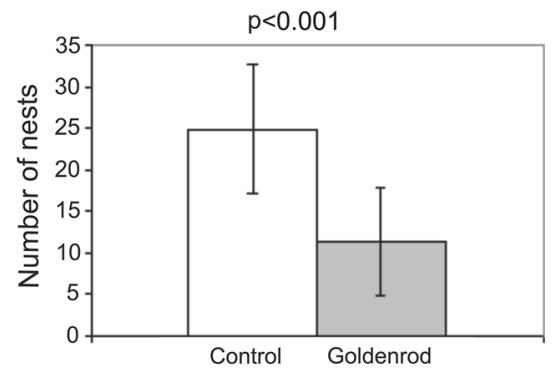

(c)

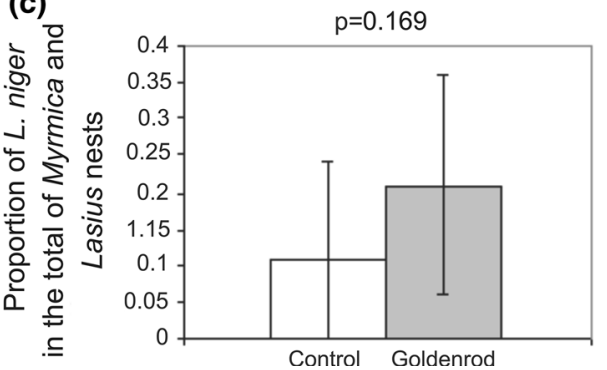

Fig. 2 The average $( \pm \mathrm{SD})$ number of species (a); number of nests (b) and ratio of the number of $L$. niger nests in the total nest number of Myrmica and Lasius species (c) in control (white bars) and goldenrod (gray bars) squares

$(0.21 \pm 0.15)$ compared to control plots $(0.11 \pm 0.13)$, but this difference was non-significant (Wilcoxon-ranked test, $\mathrm{N}=10, \mathrm{~T}=14.00, \mathrm{Z}=1.376, P=0.169$; Fig. $2 \mathrm{c}$ ).

The NMDS ordination plot suggested a possible difference in community structure between control and goldenrod plots (Fig. 3). A stress value of 0.146 suggests sufficient representation in reduced dimensions (Quinn and Keough 2002). Coefficients of determination between distances along each ordination axis and the original distances explained 46 and $36 \%$ of differences in ant communities between control and goldenrod plots (Fig. 3). One-way PERMANOVA revealed differences in ant species composition between control and goldenrod plots $\quad\left(\mathrm{N}_{\text {permutation }}=9999, \quad \mathrm{SS}=3.49\right.$, $\mathrm{MS}=2.767$. Pseudo-F $=4.701, P=0.003)$.

\section{Discussion}

Our results revealed a strong negative effect of goldenrod on the average number of ant species and ant nest density. The lower species number in goldenrod plots was

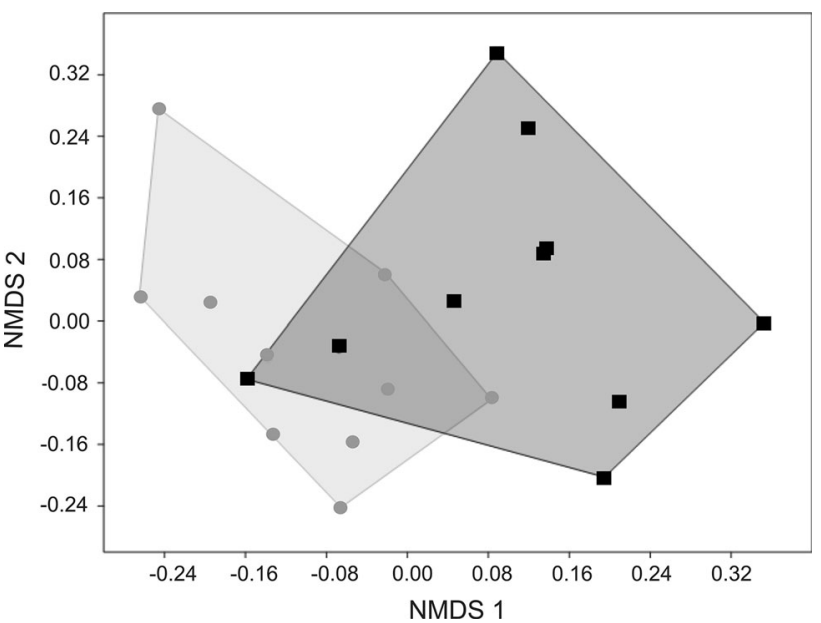

Fig. 3 NMDS ordination plot of ant species composition in control (grey circles, light grey polygon) and goldenrod (black squares, dark grey polygon) meadows. Fractions of explained variation: $\mathrm{R}_{\mathrm{NMDS} 1}^{2}=0.458, \mathrm{R}_{\mathrm{NMDS} 2}^{2}=0.357$

statistically significant despite the relatively low ant species diversity. Strikingly, a more than $50 \%$ reduction occurred in density of ant nests on goldenrod plots. Ant species composition also significantly differed between control and goldenrod plots. Species negatively affected by goldenrods included L. flavus, M. scabrinodis, M. ruginodis and $M$. rubra. The first two species are thermophilic and prefer heavily insolated areas with low vegetation (Radchenko et al. 2004). Hence, the high shading associated with goldenrod invasion most probably degraded highquality habitat previously available for these species. The status of M. scabrinodis (the most numerous species in the control plots) is particularly interesting, because its considerable decline on goldenrod plots indicates a significant change in habitat conditions. Surprisingly, populations of $M$. ruginodis were the most affected. Compared to other ants of the genus Myrmica found in this study, this species prefers shaded and slightly cooler habitats such as woodlands (Elmes et al. 1998; Radchenko et al. 2004). This habitat requirement suggests that $M$. ruginodis could potentially find favorable conditions within invaded patches. The presence of goldenrod guarantees the availability of honeydew and nectar (on which $M$. ruginodis as well as M. rubra forage; Radchenko et al. 2004), but not before July. Ant workers in areas with goldenrod forage over longer distances (Lenda et al. 2013), which may indicate lower food availability in areas invaded by goldenrod. Further studies are required to resolve the detailed mechanism of the negative effect of goldenrod on particular species. All observed Myrmica species are host ants of Phengaris butterflies (Witek et al. 2008). In the context of previous studies showing significant correlations between local extinctions of hosts and parasites (Koh et al. 2004), 
goldenrods may also have a negative effect on these flagship species. In the context of extreme local specificity of $P$. alcon for M. scabrinodis ants (Sielezniew and Stankiewicz 2002) as well as the high specificity of $P$. nausithous for $M$. rubra, goldenrod invasion potentially threatens these two butterfly species to a higher degree than the more flexible $P$. teleius which does not show local specialization to host ants (Thomas and Elmes 1998; Witek et al. 2008).

Our results suggest that only L. niger is able to sustain numerous nests in an environment changed by goldenrod. As a polyphagous species known for its high resistance to environmental change (Radchenko et al. 2004), L. niger seems to be an opportunist not threatened by invasion. The number of nests of $L$. niger can even increase because they probably start to occupy free niche space after the decline of other ant species for which the goldenrod environment is unfavorable. Although Wynhoff et al. (2011) showed that L. niger can displace competing species (L. flavus, Myrmica sp.) if habitat conditions undergo a sudden change for other reasons, e.g. heavy mowing, our study design precluded an assessment of this mechanism.

Litt et al. (2014) reviewed the literature concerning effects of invasive plants on arthropods. They found that the abundance and richness of ant species decreased with invasion of various plants (including goldenrod, see Lenda et al. 2013) in almost $50 \%$ of recent studies and increased in only $7 \%$. They suggest two main explanations for this decline. First, deterioration in the food base due to a decrease in the diversity and coverage of native plants could have triggered a decline in nectar-feeding ants (mainly $M$. rubra and M. ruginodis). Goldenrod is a strongly melliferous plant, but the time of flowering is probably too short and too late to provide enough food for invertebrates (Moroń et al. 2009). Moreover, an overall decline in species richness and densities of different groups of invertebrates in areas with goldenrod (de Groot et al. 2007; Skórka et al. 2007; Moroń et al. 2009; Fenesi et al. 2015) may cause a decrease in the amount of available food for carnivorous ant species (Litt et al. 2014), mainly $M$. scabrinodis. Many species of ants also feed on the honeydew produced by aphids. However, the effect of displacement of native plants by goldenrod on aphids is unknown. Second, the decline in ant diversity and abundance could be due to changes in microclimatic conditions (temperature, moisture, light intensity) caused by modifications in structural characteristics (increasing cover, plant height) as well as in litter accumulation and in soil characteristics (nutrients, salinity, pH) (Standish 2004; Wolkovich et al. 2009; Talley et al. 2012), which may be important especially for thermophilic species such as $M$. scabrinodis.

The impact of goldenrod invasion has already been studied in other groups of animals with a documented decrease in species richness, diversity and abundance of butterflies, wild bees and hoverflies but only a decrease in abundance in the case of ground beetles (de Groot et al. 2007; Skórka et al. 2007; Fenesi et al. 2015). The strength of these relationships depended on the trophic position occupied by the group of insects, i.e. the most strongly affected species were food specialists associated with native plants (de Groot et al. 2007). Such specialists include Phengaris butterflies which beside Myrmica ants also need obligatory host plants in their life cycle. Because invaded parts of meadows are characterized by a significantly lower number of flowering Sanquisorba officinalis and Gentiana pneumonanthe host plants (unpublished data), goldenrods may threaten Phengaris butterflies as well as other coexisting meadow species. So far no negative demographic trends in Phengaris butterfly metapopulations were noticed in the study area (Kajzer-Bonk et al. 2013). However, goldenrod invasion has only recently commenced (Moroń et al. 2009), and a large part of this particular meadow complex is still in good condition. Moreover, the abundance of $S$. officinalis does not affect densities of Phengaris butterflies (Nowicki et al. 2007). Notably, S. officinallis is typically the last native flowering plant in patches invaded by goldenrod (personal observation). Hence, the negative effect of goldenrod invasion may be delayed and later expressed as a co-extinction and a sudden collapse of Phengaris populations.

Despite evidence of the negative effects of goldenrod invasion (Skórka et al. 2007; Moroń et al. 2009), no efforts have been made to restore this valuable area. Our findings again show that immediate conservation actions should be undertaken to suppress goldenrod invasion in grassland habitats. One way is to systematically mow twice per season in May and August before seed production and remove the remaining biomass (Meyer and Schmid 1999; Weber 2000; Dőlle and Schmidt 2009). Even small fragments of grasslands utilized in a traditional and continuous manner can increase the chances of survival of typical meadow species. Proper management after goldenrod removal involves not mowing the whole area at the same time-uncut fragments constitute a refuge for many species that can later recolonize mown areas (Dauber et al. 2006). An alternative method can be controlled burning of meadow fragments, which is probably much less destructive for grassland fauna than it is believed by many conservationists (Nowicki et al. 2015). Properly conducted active grassland protection allows the restoration of ant species richness (Dahms et al. 2010) and preservation of the whole ecosystem.

Acknowledgments The study was funded by the Jagiellonian University Grant DS/WBiNoZ/INoS/761/10-12. We are very thankful to M. Bonk, K. Kuszewska and Z. Zagrodzka for their help during 
the fieldwork. P. Skórka assisted in statistical analyses. M. Bonk, P. Nowicki, M. Pabijan as well as B. Hoffmann and a second anonymous reviewer provided comments that greatly improved the manuscript.

Open Access This article is distributed under the terms of the Creative Commons Attribution 4.0 International License (http://crea tivecommons.org/licenses/by/4.0/), which permits unrestricted use, distribution, and reproduction in any medium, provided you give appropriate credit to the original author(s) and the source, provide a link to the Creative Commons license, and indicate if changes were made.

\section{References}

Abhilasha D, Quintana N, Vivanco J, Joshi J (2008) Do allelopathic compounds in invasive Solidago canadensis s.l. restrain the native European flora? J Ecol 96:993-1001

Banta JA, Stark SC, Stevens MHH, Pendergast TH IV, Baumert A, Carson WP (2008) Light reduction predicts widespread patterns of dominance between asters and goldenrods. Plant Ecol 199:65-76

Callaway RM, Aschehoug ET (2000) Invasive plants versus their new and old neighbors: a mechanism for exotic invasion. Science 290:521-523

Crist TO (2009) Biodiversity, species interactions, and functional roles of ants (Hymenoptera: Formicidae) in fragmented landscapes: a review. Myrmecol News 12:3-13

Dahms H, Lenoir L, Lindborg R, Wolters V, Dauber J (2010) Restoration of seminatural grasslands: what is the impact on ants? Restor Ecol 18:330-337

Dauber J, Bengtsson J, Lenoir L (2006) Evaluating effects of habitat loss and land-use continuity on ant species richness in seminatural grassland remnants. Conserv Biol 20:1150-1160

Dauber J, Niechoj R, Baltruschat H, Wolters V (2008) Soil engineering ants increase grass root arbuscular mycorrhizal colonization. Biol Fertil Soils 44:791-796

de Groot M, Kleijn D, Jogan N (2007) Species groups occupying different trophic levels respond differently to the invasion of semi-natural vegetation by Solidago canadensis. Biol Conserv 136:612-617

Dőlle M, Schmidt W (2009) The relationship between soil seed bank, above-ground vegetation and disturbance intensity on old-field successional permanent plots. Appl Veg Sci 12:415-428

Dostál P (2007) Population dynamics of annuals in perennial grassland controlled by ants and environmental stochasticity. J Veg Sci 18:91-102

Elmes GW, Thomas JA, Wardlaw JC, Hochberg ME, Clarke RT, Simcox DJ (1998) The ecology of Myrmica ants in relation to the conservation of Maculinea butterflies. J Insect Conserv 2:67-78

Fenesi A, Vágási CI, Beldean M, Földesi R, Kolcsár L, Shapiro JT, Török E, Kovács-Hostyánszki A (2015) Solidago canadensis impacts on native plant and pollinator communities in differentaged old fields. Basic Appl Ecol 16:335-346

Folgarait PJ (1998) Ant biodiversity and its relationship to ecosystem functioning: a review. Biodivers Conserv 7:1221-1244

Frouz J, Jilková V (2008) The effect of ants on soil properties and processes (Hymenoptera: Formicidae). Myrmecol News 11:191-199

Gorb EV, Filippov AE, Gorb SN (2013) Long-term ant-speciesdependent dynamics of a myrmecochorous plant community. Arthropod-Plant Interact 7:277-286

Guillem RM, Drijfhout FP, Martin SJ (2012) Using chemo-taxonomy of host ants to help conserve the large blue butterfly. Biol Conserv 148:39-43
Habel JC, Dengler J, Janisova M, Török P, Wellstein C, Wiezik M (2013) European grassland ecosystems: threatened hotspots of biodiversity. Biodivers Conserv 22:2131-2138

Hartnett DC, Bazzaz FA (1985) The genet and ramet population dynamics of Solidago canadensis in an abandoned field. J Ecol 73:407-413

Jobin A, Schaffner U, Nentwig W (1996) The structure of the phytophagous insect fauna on the introduced weed Solidago altissima in Switzerland. Entomol Exp Appl 79:33-42

Joyce CB (2014) Ecological consequences and restoration potential of abandoned wet grasslands. Ecol Eng 66:91-102

Kabuce N, Priede N (2010) NOBANIS-invasive alien species fact sheet-Solidago canadensis. Online database of the European network on invasive alien species-NOBANIS. www.nobanis. org

Kajzer-Bonk J, Nowicki P, Bonk M, Skórka P, Witek M, Woyciechowski M (2013) Local populations of endangered Maculinea (Phengaris) butterflies are flood resistant. J Insect Conserv 17:1105-1112

Koh LP, Dunn RR, Sodhi NS, Colwell RK, Proctor HC, Smith VS (2004) Species coextinctions and the biodiversity crisis. Science 305:1632-1634

Lenda M, Witek M, Skórka P, Moroń D, Woyciechowski M (2013) Invasive alien plants affect grassland ant communities, colony size and foraging behavior. Biol Invasions 15:2403-2414

Litt AR, Cord EE, Fulbright TE, Schuster GL (2014) Effects of invasive plants on arthropods. Conserv Biol 28:1532-1549

Łomnicki A (2010) Wprowadzenie do statystyki dla przyrodników. PWN, Warszawa

Luoto M, Pykälä J, Kuussaari M (2003) Decline of landscape-scale habitat and species diversity after the end of cattle grazing. J Nat Conserv 11:171-178

Meyer AH, Schmid B (1999) Seed dynamics and seedling establishment in the invading perennial Solidago altissima under different experimental treatments. J Ecol 87:28-41

Mitchell CE, Power AG (2003) Release of invasive plants from fungal and viral pathogens. Nature 421:625-627

Moroń D, Lenda M, Skórka P, Szentgyörgyi H, Settele J, Woyciechowski M (2009) Wild pollinator communities are negatively affected by invasion of alien goldenrods in grassland landscapes. Biol Conserv 142:1322-1332

Nowicki P, Pepkowska A, Kudlek J, Skórka P, Witek M, Settele J, Woyciechowski M (2007) From metapopulation theory to conservation recommendations: lessons from spatial occurrence and abundance patterns of Maculinea butterflies. Biol Conserv 140:119-129

Nowicki P, Marczyk J, Kajzer-Bonk J (2015) Metapopulations of endangered Maculinea butterflies are resilient to large-scale fire. Ecohydrology 8:398-405

Petal J (1980) Ant populations, their regulation and effect on soil in meadows. Ekol Pol 28:297-326

Queiroz C, Beilin R, Folke C, Lindborg R (2014) Farmland abandonment: threat or opportunity for biodiversity conservation? A global review. Front Ecol Environ 12:288-296

Quinn GP, Keough MJ (2002) Experimental design and data analysis for biologists. Cambridge University Press, Cambridge

Radchenko A, Czechowska W, Czechowski W (2004) Klucze do oznaczania owadów polski, część XXIV-błonkówki-Hymenoptera, zeszyt 63-Mrówki-Formicidae. Polskie Towarzystwo Entomologiczne, Toruń

Servigne P, Detrain C (2008) Ant-seed interactions: combined effects of ant and plant species on seed removal patterns. Insectes Soc $55: 220-230$

Sielezniew M, Stankiewicz A (2002) First data on host-ant specificity of parasitic Maculinea alcon (Den. \& Schiff.) (Lepidoptera: 
Lycaenidae) in Poland and eastern Europe. Fragmenta Faunistica 45:123-130

Skórka P, Settele J, Woyciechowski M (2007) Effects of management cessation on grassland butterflies in southern Poland. Agric Ecosyst Environ 121:319-324

Skórka P, Lenda M, Tryjanowski P (2010) Invasive alien goldenrods negatively affect grassland bird communities in Eastern Europe. Biol Conserv 143:856-861

Standish RJ (2004) Impact of an invasive clonal herb on epigaeic invertebrates in forest remnants in New Zealand. Biol Conserv 116:49-58

Talley TS, Nguyen K-C, Nguyen A (2012) Testing the effects of an introduced palm on a riparian invertebrate community in southern California. PLoS One. doi:10.1371/journal.pone. 0042460

Thomas JA, Elmes GW (1998) Higher productivity at the cost of increased host-specificity when Maculinea butterfly larvae exploit ant colonies through trophallaxis rater than by predation. Ecol Entomol 23:457-464

Thomas JA, Settele J (2004) Butterfly mimics of ants. Nature 432:283-284

Thomas JA, Elmes GW, Wardlaw JC, Woyciechowski M (1989) Host specificity among Maculinea butterflies in Myrmica ant nests. Oecologia 79:452-457

Underwood EC, Fisher BL (2006) The role of ants in conservation monitoring: if, when, and how. Biol Conserv 132:166-182
Weber E (1998) The dynamics of plant invasions: a case study of three exotic goldenrod species (Solidago L.) in Europe. J Biogeogr 25:147-154

Weber E (2000) Biological flora of Central Europe: Solidago altissima L. Flora 195:123-134

Weber E (2001) Current and potential ranges of three exotic goldenrods (Solidago) in Europe. Conserv Biol 15:122-128

Weber E (2011) Strong regeneration ability from rhizome fragments in two invasive clonal plants (Solidago canadensis and $S$. gigantea). Biol Invasions 13:2947-2955

Wikum DA, Shanholtzer GF (1978) Application of the BraunBlanquet cover-abundance scale for vegetation analysis in land development studies. Environ Manag 2:323-329

Witek M, Śliwińska EB, Skórka P, Nowicki P, Wantuch M, Vrabec V, Settele J, Woyciechowski M (2008) Host ant specificity of large blue butterflies Phengaris (Maculinea) (Lepidoptera: Lycaenidae) inhabiting humid grasslands in East-central Europe. Eur J Entomol 105:871-877

Wolkovich EM, Bolger DT, Holway DA (2009) Complex responses to invasive grass litter by ground arthropods in a Mediterranean scrub ecosystem. Oecologia 161:697-708

Wynhoff I, van Gestel R, van Swaay C, van Langevelde F (2011) Not only the butterflies: managing ants on road verges to benefit Phengaris (Maculinea) butterflies. J Insect Conserv 15:189-206

Wysocki C, Sikorski P (2002) Fitosocjologia stosowana. Wydawnictwo SGGW, Warszawa 